\title{
Congenital myopathies in the adult neuromuscular clinic
}

\section{Diagnostic challenges and pitfalls} Stefan Nicolau, MD, Teerin Liewluck, MD, Jennifer A. Tracy, MD, Ruple S. Laughlin, MD, and
Margherita Milone, MD, PhD

Neurol Genet 2019;5:e341. doi:10.1212/NXG.0000000000000341

\author{
Correspondence \\ Dr. Milone \\ milone.margherita@mayo.edu
}

\begin{abstract}
\section{Objective}

To investigate the spectrum of undiagnosed congenital myopathies (CMs) in adults presenting to our neuromuscular clinic and to identify the pitfalls responsible for diagnostic delays.
\end{abstract}

\section{Methods}

We conducted a retrospective review of patients diagnosed with $\mathrm{CM}$ in adulthood in our neuromuscular clinic between 2008 and 2018. Patients with an established diagnosis of CM before age 18 years were excluded.

\section{Results}

We identified 26 patients with adult-onset $\mathrm{CM}$ and 18 patients with pediatric-onset $\mathrm{CM}$ who were only diagnosed in adulthood. Among patients with adult onset, the median age at onset was 47 years, and the causative genes were RYR1 (11 families), MYH7 (3 families) and ACTA1 (2 families), and SELENON, MYH2, DNM2, and CACNA1S (1 family each). Of 33 patients who underwent muscle biopsy, only 18 demonstrated histologic abnormalities characteristic of $\mathrm{CM}$. Before their diagnosis of CM, 23 patients had received other diagnoses, most commonly non-neurologic disorders. The main causes of diagnostic delays were mildness of the symptoms delaying neurologic evaluation and attribution of the symptoms to coexisting comorbidities, particularly among pediatric-onset patients.

\section{Conclusions}

CMs in adulthood represent a diagnostic challenge, as they may lack the clinical and myopathologic features classically associated with $\mathrm{CM}$. Our findings underscore the need for a revision of the terminology and current classification of these disorders. 


\section{Glossary}

CFTD = congenital fiber-type disproportion; $\mathbf{C K}=$ creatine kinase; $\mathbf{C M}=$ congenital myopathy; $\mathbf{M R C}=$ Medical Research Council; MUP = motor unit potential; NGS = next-generation sequencing; VUS = variants of unknown significance.

Congenital myopathies (CMs) are a group of inherited myopathies most commonly presenting in infancy with hypotonia and weakness. ${ }^{1,2}$ Some patients may also have facial weakness, ptosis, ophthalmoparesis, respiratory insufficiency, cardiac involvement, or skeletal abnormalities. Generally, the weakness is either static or very slowly progressive. ${ }^{3-6} \mathrm{CMs}$ are rare disorders and, as a group, have an estimated prevalence of $0.6-2$ per 100,000 individuals. ${ }^{7,8}$ Traditionally, CMs have been classified on the basis of distinctive myopathologic features, such as nemaline rods, cores, multiminicores, central nuclei, or congenital fiber-type disproportion (CFTD). ${ }^{9}$ Each histologic subtype is genetically heterogeneous, and over $25 \mathrm{CM}$ genes have been identified. ${ }^{10}$ In addition, a spectrum of myopathologic changes may stem from the same molecular defect, even within the same family. ${ }^{11}$

Increasing use of genetic testing and application of nextgeneration sequencing (NGS) has identified patients with variants in genes known to cause CM but who lack the histologic and clinical features typically associated with CM. This phenomenon is well recognized in RYR1-related myopathies, in which approximately $40 \%$ of patients present with core myopathy, ${ }^{12}$ whereas others present with malignant hyperthermia or recurrent rhabdomyolysis without histopathologic abnormalities. ${ }^{12,13}$ Moreover, CM can manifest in adulthood, as reported with $\mathrm{CM}$ caused by variants in RYR $1,{ }^{12} \mathrm{DNM} 2,{ }^{14}$ ACTA $1,{ }^{15,16}$ BIN $1,{ }^{17} \mathrm{MYH} 7,{ }^{18}$ and KBTBD13. ${ }^{19}$ Despite these reports, the prevalence of adult-onset $\mathrm{CM}$ remains unknown, and their characteristics have not been systematically studied. We therefore sought to investigate the clinical, histopathologic, and genetic features of adult patients with undiagnosed CM presenting to our neuromuscular clinic to (1) characterize the spectrum of adult-onset CM and (2) identify pitfalls leading to diagnostic delays among both pediatric- and adult-onset patients.

\section{Methods}

\section{Patient selection}

We searched the medical records of the Mayo Clinic in Rochester, MN, for patients evaluated in the neurology department between July 1, 2008, and June 30, 2018, and who received a diagnosis of $\mathrm{CM}$ in adulthood (age $\geq 18$ years). A diagnosis of $\mathrm{CM}$ was established either on the basis of genetic testing or muscle histopathology. Patients found to have a disease-causing variant in a gene known to cause $\mathrm{CM}^{10}$ were included. Patients without a molecular diagnosis were included only if their muscle biopsy demonstrated distinctive histopathologic features of CM (centronuclear myopathy, nemaline rods, central cores, combined cores and rods, multiminicores, or CFTD) in the absence of an alternative clinicopathologic or genetic diagnosis. Because of the overlapping phenotypes of $\mathrm{CM}$ and other inherited neuromuscular disorders, patients without a molecular diagnosis or distinctive histologic findings were not included. Patients with sporadic late-onset nemaline myopathy were excluded, as this is an acquired disorder. ${ }^{20}$ Patients diagnosed with congenital muscular dystrophies were also excluded. ${ }^{21-23}$ All patients with a diagnosis of CM established on clinical, histologic, or genetic grounds before age 18 years were excluded.

\section{Clinical and laboratory evaluation}

Medical records were retrospectively reviewed, and data were collected regarding patients' age at onset, clinical features, and disease course. The severity of weakness was graded according to the Medical Research Council (MRC) scale and classified as absent (MRC $5 / 5)$, mild $(4 / 5)$, moderate $(3 / 5)$, or severe $(0-2 / 5)$. Results of genetic testing, electrodiagnostic studies, creatine kinase (CK) levels, complete blood count, and cardiac and pulmonary function tests were reviewed.

\section{Muscle pathology}

Muscle biopsies performed at our institution were processed as previously described, ${ }^{24}$ and biopsies performed at outside institutions were reviewed.

\section{Statistical methods}

Patients were divided into subgroups according to age at onset and molecular diagnosis. Patient characteristics are presented as counts, medians, and ranges. The number of patients with missing data is indicated.

\section{Standard protocol approvals, registrations, and patient consents}

The Mayo Clinic institutional review board approved this study.

\section{Data availability}

Anonymized data will be shared by request from any qualified investigator.

\section{Results}

\section{Patients and genetic testing}

Forty-four patients from 36 unrelated families met the inclusion criteria. A molecular diagnosis was established in 37 patients from 29 families (figure). The most common causative genes were RYR1 (13 families), ACTA1 (5 families), SELENON (4 families), MYH7 (3 families), MYH2, TPM2, DNM2, and CACNA1S (1 family each). The mode of inheritance of the disorders was autosomal recessive in the patients with $M Y H 2$ and SELENON variants and 1 patient with ACTA1 myopathy. Inheritance was autosomal dominant in families with ACTA1, TPM2, MYH7, DNM2, and CACNA1S 
Figure Genes causative of congenital myopathies in our cohort
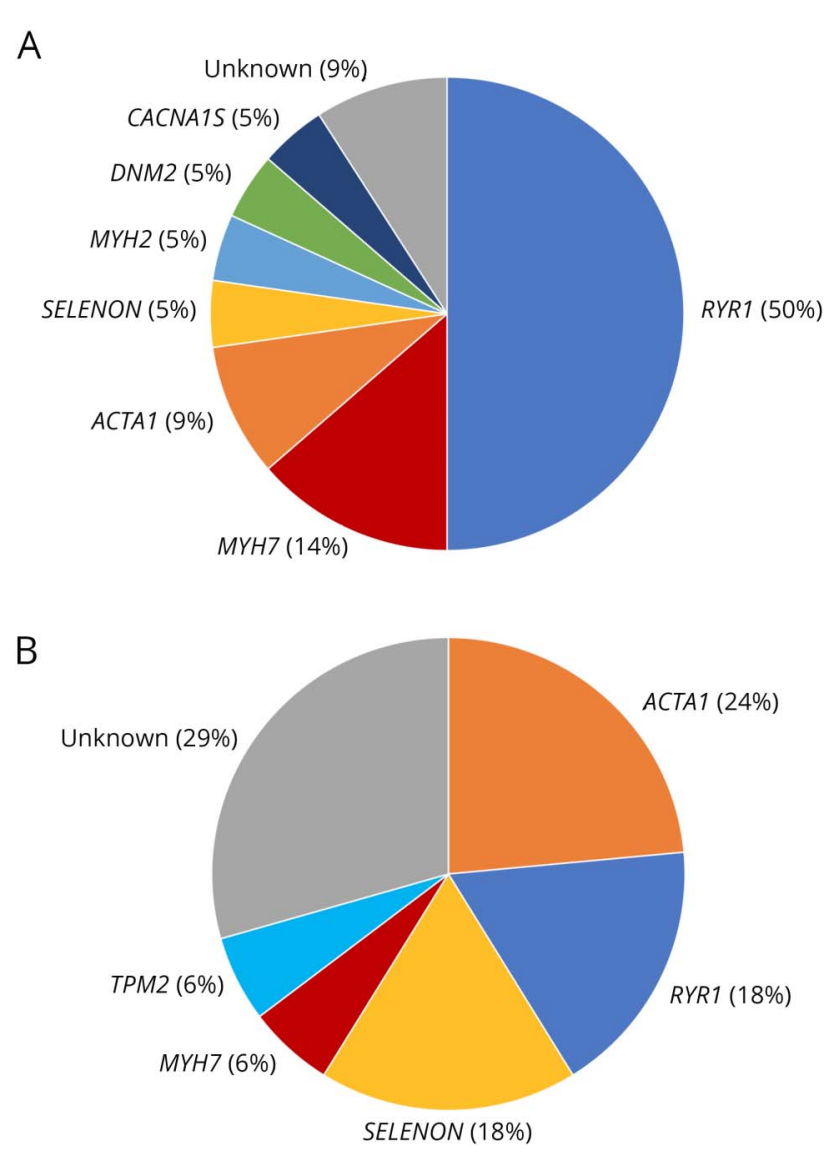

Percentages indicate the proportion of families with the corresponding genetic defect among (A) adult-onset and (B) pediatric-onset patients diagnosed in adulthood.

variants and at least 12 families with $R Y R 1$ variants. The dominant inheritance of the $R Y R 1$ variants was established by previous reports (10 families) or occurrence of the variant in affected parent-child pairs (2 families). One patient had a single novel RYR1 frameshift variant. Although we could not ascertain its dominant or recessive inheritance, this was the only candidate variant identified in this patient, and there have been previous reports of dominant inheritance with truncating variants in $R Y R 1 .^{25,26}$ In 2 families with dominant inheritance, however, additional variants may have contributed to the clinical phenotype, as previously reported (table e- 1 , links.lww.com/NXG/A158). ${ }^{25,27}$

The molecular diagnosis was first established by single gene sequencing in 8 families, by an NGS gene panel in 18 families, and by whole-exome sequencing in 3 families. In total, 29 distinct genetic variants were identified (table e-1, links.lww. com/NXG/A158). In 7 of the 44 patients, no molecular diagnosis could be established, and the diagnosis of $\mathrm{CM}$ was therefore made on histopathologic grounds. Five of these patients had no genetic testing; 1 patient with CFTD underwent an NGS panel targeting 22 known CM genes, and another with centronuclear myopathy only underwent Sanger sequencing of the MTM1 and DNM2 genes.

A history of more than 1 affected family member was present in 22 of 36 families. In 7 families, the discovery of a molecular diagnosis in the proband led to confirmation of the diagnosis in additional family members. These were all first-degree relatives of the probands. All individuals thus identified underwent neurologic examination, with the exception of 1 affected family member who was not available for a face-to-face assessment.

Seventeen additional patients were found to harbor variants of unknown significance (VUS) in CM genes, as classified according to the American College of Medical Genetics criteria. ${ }^{28}$ Fourteen of these 17 patients had variants in RYR1, whereas single patients had variants in MYH7, SELENON and CCDC78. There was no clinical or histologic evidence to support the possible pathogenicity of these VUS. These patients were therefore not included.

\section{Pediatric-onset patients with delayed diagnosis}

Eighteen patients had onset of symptoms before age 18 years but received a diagnosis of CM in adulthood (table 1). The causative genes were ACTA1 (5 patients), RYR1 (3), SELENON (3), MYH7 and TPM2 (1 each). Onset of symptoms varied from infancy to adolescence, whereas the median age at diagnosis was 40 years.

Various factors contributed to the diagnostic delay in these patients. Ten patients did not undergo relevant investigations before adulthood because of the mildness of their symptoms. Three patients had no muscle biopsy and were diagnosed with Becker muscular dystrophy, myasthenia gravis, and spinal muscular atrophy. ${ }^{11}$ Four patients underwent muscle biopsy, which showed nonspecific abnormalities, and were diagnosed with muscular dystrophy.

\section{Adult-onset patients}

Twenty-six patients had onset of symptoms in adulthood (table 2). The most common causative gene was RYR1 (13 patients), followed by ACTA1 (3), MYH7 (3), DNM2 (2), and SELENON, MYH2, and CACNA1S (1 each). The median age at onset was 47 years. Eight patients retrospectively reported athletic performance below their peers since childhood, which had not previously been thought to be abnormal. Sixteen patients described a progressive course, whereas 4 indicated a static course. Three patients reported only episodic symptoms, such as rhabdomyolysis or malignant hyperthermia, and 3 patients presented with asymptomatic hyperCKemia.

Twenty of the 25 examined patients had muscle weakness, which was mild (9 patients), moderate (7), or severe (4). When present, weakness most commonly affected limb-girdle muscles. Two patients started to use a wheelchair (with ACTA1 and RYR1 myopathy). Two patients (1 with ACTA1 myopathy and 1 with RYR1 myopathy) had mild dysphagia. 
Table 1 Clinical and laboratory features of pediatric-onset congenital myopathies diagnosed in adulthood

\begin{tabular}{|c|c|c|c|c|c|c|c|}
\hline & MYH7 & ACTA1 & TPM2 & SELENON & RYR1 & None & Total \\
\hline No. of patients (families) & $1(1)$ & $5(4)$ & $1(1)$ & $3(3)$ & $3(3)$ & $5(5)$ & $18(17)$ \\
\hline Age at onset-median (range) & 10 & $2(0-15)$ & 17 & $1(1-5)$ & $14(10-15)$ & $0(0-12)$ & $5(0-17)$ \\
\hline Age at diagnosis-median (range) & 67 & $52(24-69)$ & 56 & $34(24-42)$ & $34(32-57)$ & $37(19-46)$ & $40(19-69)$ \\
\hline \multicolumn{8}{|l|}{ Clinical course } \\
\hline Static & & 1 & 1 & & & 2 & 4 \\
\hline Progressive & 1 & 4 & & 3 & 1 & 3 & 12 \\
\hline Fluctuating/episodic & & & & & 2 & & 2 \\
\hline \multicolumn{8}{|l|}{ Degree of weakness } \\
\hline None & & & & & 1 & & 1 \\
\hline Mild & & & 1 & & 2 & 2 & 5 \\
\hline Moderate & & 3 & & 3 & & 2 & 8 \\
\hline Severe & 1 & 2 & & & & 1 & 4 \\
\hline
\end{tabular}

\section{Pattern of weakness}

\begin{tabular}{|c|c|c|c|c|c|c|c|}
\hline Limb girdle & & 1 & 1 & 2 & 1 & 2 & 7 \\
\hline Distal & 1 & 2 & & & 1 & 1 & 5 \\
\hline Generalized & & 2 & & 1 & & 2 & 5 \\
\hline \multicolumn{8}{|l|}{ Other clinical features } \\
\hline Facial weakness & 0 & 5 & 1 & 3 & 0 & 4 & 13 \\
\hline Ptosis & 0 & 0 & 0 & 0 & 0 & 1 & 1 \\
\hline Ophthalmoparesis & 0 & 0 & 0 & 0 & 0 & 0 & 0 \\
\hline Skeletal abnormalities & 1 & 3 & 1 & 2 & 1 & 4 & 12 \\
\hline Cardiomyopathy & $0 / 1$ & $1 / 4$ & $0 / 1$ & $0 / 3$ & $1 / 2$ & $1 / 4$ & $3 / 15$ \\
\hline Respiratory involvement & & $2 / 4$ & $1 / 1$ & $3 / 3$ & $1 / 1$ & $5 / 5$ & $12 / 14$ \\
\hline \multicolumn{8}{|l|}{ Creatine kinase } \\
\hline Elevated & $0 / 1$ & $1 / 4$ & $0 / 1$ & $0 / 3$ & $2 / 3$ & $0 / 2$ & $3 / 14$ \\
\hline Median (range) & $\mathrm{N}$ & $N(N-222)$ & $\mathrm{N}$ & $\mathrm{N}$ & $412(N-572)$ & $\mathrm{N}$ & $N(N-572)$ \\
\hline \multicolumn{8}{|l|}{ EMG } \\
\hline Short-duration MUPs & $1 / 1$ & $5 / 5$ & $1 / 1$ & $3 / 3$ & $3 / 3$ & $3 / 4$ & $16 / 17$ \\
\hline Long-duration MUPs & $1 / 1$ & $3 / 5$ & $1 / 1$ & $0 / 3$ & $2 / 3$ & $0 / 4$ & $7 / 17$ \\
\hline Fibrillation potentials & $1 / 1$ & $4 / 5$ & $0 / 1$ & $2 / 3$ & $2 / 3$ & $1 / 4$ & $10 / 17$ \\
\hline \multicolumn{8}{|l|}{ Muscle pathology } \\
\hline Distinctive abnormalities ( $\mathrm{n}$ ) & & CFTD (1) & CFTD (1) & MMC (1) & Central cores (1) & $\begin{array}{l}\text { MMC (2), CNM (1), CFTD (1), } \\
\text { central nuclei and cores (1) }\end{array}$ & 9 \\
\hline Nonspecific abnormalities & 1 & 3 & & 1 & & & 5 \\
\hline Normal & & & & & 1 & & 1 \\
\hline
\end{tabular}

Abbreviations: $\mathrm{CFTD}=$ congenital fiber-type disproportion; $\mathrm{CNM}=$ centronuclear myopathy; $\mathrm{MMC}=$ multiminicore; $\mathrm{MUP}=$ motor unit potential; $\mathrm{N}=$ normal Denominators denote the number of patients for whom data are available. 
Table 2 Clinical and laboratory features of patients with adult-onset congenital myopathy

\begin{tabular}{|c|c|c|c|c|c|c|c|c|c|}
\hline & MYH2 & MYH7 & ACTA1 & DNM2 & SELENON & RYR1 & CACNA1S & None & Total \\
\hline $\begin{array}{l}\text { No. of patients } \\
\text { (families) }\end{array}$ & $1(1)$ & $3(3)$ & $3(2)$ & $2(1)$ & $1(1)$ & $13(11)$ & $1(1)$ & $2(2)$ & $26(22)$ \\
\hline $\begin{array}{l}\text { Age at onset-median } \\
\text { (range) }\end{array}$ & 26 & 47 & $\begin{array}{l}34 \\
(29-49)\end{array}$ & $\begin{array}{l}48 \\
(31-65)\end{array}$ & 32 & $53(25-72)$ & 36 & $49(40-59)$ & $\begin{array}{l}47 \\
(25-72)\end{array}$ \\
\hline $\begin{array}{l}\text { Age at } \\
\text { diagnosis-median } \\
\text { (range) }\end{array}$ & 33 & 48 & $\begin{array}{l}34 \\
(31-58)\end{array}$ & $\begin{array}{l}61 \\
(51-72)\end{array}$ & 34 & $55(25-84)$ & 36 & $57(55-60)$ & $\begin{array}{l}52 \\
(25-84)\end{array}$ \\
\hline
\end{tabular}

\section{Clinical course}

\begin{tabular}{|c|c|c|c|c|c|c|c|c|c|}
\hline Asymptomatic & & & & & & 3 & & & 3 \\
\hline Static & 1 & & 1 & & & 2 & & & 4 \\
\hline Progressive & & 3 & 2 & 2 & 1 & 6 & & 2 & 16 \\
\hline Fluctuating/episodic & & & & & & 2 & 1 & & 3 \\
\hline Degree of weakness & & & & & & & & & \\
\hline None & & & & & & 4 & 1 & & 5 \\
\hline Mild & & 1 & 1 & 1 & & 6 & & & 9 \\
\hline Moderate & 1 & & 2 & 1 & 1 & 1 & & 1 & 7 \\
\hline Severe & & 2 & & & & 1 & & 1 & 4 \\
\hline
\end{tabular}

Pattern of weakness

\begin{tabular}{|c|c|c|c|c|c|c|c|c|c|}
\hline Limb girdle & 1 & 1 & 1 & 2 & 1 & 6 & & 1 & 13 \\
\hline Distal & & 1 & 1 & & & 2 & & & 4 \\
\hline Scapuloperoneal & & 1 & 1 & & & & & & 2 \\
\hline Generalized & & & & & & & & 1 & 1 \\
\hline \multicolumn{10}{|l|}{ Other clinical features } \\
\hline Facial weakness & 1 & 1 & 2 & 1 & 1 & 3 & 0 & 1 & 10 \\
\hline Ptosis & 1 & 0 & 0 & 0 & 0 & 0 & 0 & 0 & 1 \\
\hline Ophthalmoparesis & 1 & 0 & 0 & 0 & 0 & 0 & 0 & 0 & 1 \\
\hline $\begin{array}{l}\text { Skeletal } \\
\text { abnormalities }\end{array}$ & 1 & 1 & 1 & 1 & 1 & 2 & 0 & 1 & 8 \\
\hline Cardiomyopathy & $0 / 1$ & $2 / 3$ & $1 / 3$ & $1 / 2$ & $0 / 1$ & $3 / 7$ & $0 / 1$ & $0 / 2$ & $7 / 20$ \\
\hline $\begin{array}{l}\text { Respiratory } \\
\text { involvement }\end{array}$ & $0 / 1$ & $1 / 2$ & $1 / 2$ & $2 / 2$ & $1 / 1$ & $2 / 2$ & & $0 / 2$ & $7 / 12$ \\
\hline \multicolumn{10}{|l|}{ Creatine kinase } \\
\hline Elevated & $1 / 1$ & $2 / 3$ & $0 / 3$ & $1 / 2$ & $0 / 1$ & $12 / 13$ & $1 / 1$ & $1 / 2$ & $18 / 26$ \\
\hline Median (range) & 457 & $\begin{array}{l}974 \\
(N-6685)\end{array}$ & $\mathrm{N}$ & $\begin{array}{l}137 \\
(\mathrm{~N}-177)\end{array}$ & $\mathrm{N}$ & $703(\mathrm{~N}-2800)$ & 895 & $214(N-397)$ & $\begin{array}{l}536 \\
(\mathrm{~N}-6685)\end{array}$ \\
\hline \multicolumn{10}{|l|}{ EMG } \\
\hline Short-duration MUPs & $1 / 1$ & $2 / 3$ & $3 / 3$ & $1 / 2$ & $1 / 1$ & $9 / 10$ & $0 / 1$ & $2 / 2$ & $19 / 23$ \\
\hline Long-duration MUPs & $1 / 1$ & $0 / 3$ & $3 / 3$ & $0 / 2$ & $0 / 1$ & $2 / 10$ & $0 / 1$ & $0 / 2$ & $6 / 23$ \\
\hline $\begin{array}{l}\text { Fibrillation } \\
\text { potentials }\end{array}$ & $0 / 1$ & $3 / 3$ & $1 / 3$ & $1 / 2$ & $0 / 1$ & $5 / 10$ & $0 / 1$ & $0 / 2$ & $10 / 23$ \\
\hline
\end{tabular}


Table 2 Clinical and laboratory features of patients with adult-onset congenital myopathy (continued)

\begin{tabular}{|c|c|c|c|c|c|c|c|c|c|}
\hline & MYH2 & MYH7 & ACTA1 & DNM2 & SELENON & RYR1 & CACNA1S & None & Total \\
\hline \multicolumn{10}{|l|}{ Muscle pathology } \\
\hline $\begin{array}{l}\text { Distinctive } \\
\text { abnormalities (n) }\end{array}$ & & & NR (2) & CNM (1) & & $\begin{array}{l}\text { Central core (2), } \\
\text { CNM (1) }\end{array}$ & $\begin{array}{l}\text { Core-like } \\
\text { structures (1) }\end{array}$ & $\begin{array}{l}\text { CNM (1), } \\
\text { MMC (1) }\end{array}$ & 9 \\
\hline $\begin{array}{l}\text { Nonspecific } \\
\text { abnormalities }\end{array}$ & $1^{a}$ & 2 & & & 1 & 5 & & & 9 \\
\hline
\end{tabular}

Abbreviations: CFTD = congenital fiber-type disproportion; CNM = centronuclear myopathy; MMC = multiminicore; $M U P=$ motor unit potential; $\mathrm{N}=$ normal; $\mathrm{NR}=$ nemaline rod.

Denominators denote the number of patients for whom data are available.

${ }^{a}$ Aggregates of several sarcomeric proteins.

Rhabdomyolysis occurred in 4 patients ( 3 with $R Y R 1$ variants and 1 with a CACNA1S variant), whereas a history of malignant hyperthermia was elicited in 3 patients, all of whom had RYR1 variants.

Skeletal abnormalities were present in 8 patients, including joint contractures (3 patients), pes cavus (3), lumbar hyperlordosis (3), scoliosis (2), high-arched palate (1), and rigid spine (1). By contrast, skeletal abnormalities were seen in 12/ 18 pediatric-onset patients.

At least 13 adult-onset patients received one or more incorrect diagnosis before the diagnosis of $\mathrm{CM}$. The most common misdiagnoses were non-neurologic disorders (7 patients), followed by statin-induced myopathy (3), neuropathies (2), mitochondrial myopathy, and limb-girdle muscular dystrophy (1 each). Two patients received immunosuppressive treatment as a result of misdiagnoses.

\section{Cardiac and respiratory involvement}

Cardiomyopathy was present in 10 of 35 patients who had undergone an echocardiogram, excluding patients with cor pulmonale secondary to respiratory insufficiency. Cardiomyopathy was seen in patients with variants in MYH7, ACTA1, $D N M 2$, and RYR1. Respiratory muscle involvement was present in 19/26 patients who had undergone overnight oximetry or pulmonary function testing, including maximal respiratory pressures. Seven patients required noninvasive ventilatory support and 1 required mechanical ventilation. Ventilatory support was more frequently needed in pediatriconset than adult-onset patients (6 and 2, respectively). Respiratory involvement was most common and most severe in patients with SELENON myopathy. In 2/4 SELENON myopathy patients, respiratory failure was the first presenting symptom and all 4 eventually required ventilatory support. There was no association between severity of appendicular weakness and either cardiomyopathy or respiratory involvement.

\section{Laboratory and electrodiagnostic features}

The CK level was elevated in $3 / 14$ pediatric-onset patients and 18/26 adult-onset patients in whom data were available. CK elevations were most common in patients with RYR1 myopathy. Forty patients underwent EMG. Needle EMG showed short-duration motor unit potentials (MUPs) in 35 patients. Thirteen patients additionally had long-duration MUPs; these were most commonly found in ACTA1 myopathy, being present in 6/8 patients. Long-duration MUPs alone were not observed. Fibrillation potentials were seen in 20 patients. A sensorimotor polyneuropathy was found in 4 patients, 2 of whom had evidence of an acquired cause. Repetitive nerve stimulation did not show a significant $(>10 \%)$ decrement in any of the 15 patients tested, including 2 patients with centronuclear myopathy. All 6 patients who lacked weakness on examination did have elevated CK levels, short-duration MUPs on EMG, or both.

\section{Muscle pathology}

Thirty-three patients underwent muscle biopsy. Among 26 of these patients in whom a molecular diagnosis was established, only 11 had the distinctive histopathologic findings of a CM, including central core disease (4 patients), nemaline rods (2), CFTD (2), centronuclear myopathy (2), and multiminicore disease (1). By contrast, 14 biopsies demonstrated only nonspecific myopathic findings, such as increased variation in fiber size, increased numbers of internal nuclei, necrotic and regenerating fibers, and increased endomysial connective tissue. One biopsy was normal. Distinctive histologic findings were seen in similar proportions of pediatric- and adult-onset patients (9/15 and $9 / 18$, respectively).

Among the 7 patients without a molecular diagnosis, muscle biopsy demonstrated multiminicore disease (3 patients), centronuclear myopathy (2), CFTD (1), and both central nuclei and cores (1). A molecular diagnosis was established in $11 / 13$ patients $(85 \%)$ with specific histopathologic findings who had undergone genetic testing.

\section{Discussion}

The present study examined patients in whom a diagnosis of $\mathrm{CM}$ was established in adulthood. We aimed to characterize the spectrum of phenotypic variability and unravel pitfalls leading to the diagnostic delays experienced by these patients. We therefore selected patients in whom a diagnosis of $\mathrm{CM}$ was established after age 18 years on clinical, pathologic, and genetic grounds. 
Eighteen of the patients thus identified had onset of symptoms before age 18 years but were only diagnosed at a median age of 40 years. Among these patients, the most frequent cause of diagnostic delays was a failure to obtain any neurologic investigations for symptoms that were considered benign or attributed to non-neurologic conditions. In other patients, it was not recognized that the nonspecific changes on muscle biopsy could nonetheless signal a CM.

In 26 other patients, the onset of symptoms was in adulthood. Several of these patients retrospectively reported poor athletic performance in childhood. Such data may suggest that the true age at onset of the $\mathrm{CM}$ in some cases preceded the reported onset without being recognized. Poor athletic performance, however, is a nonspecific feature, as there are many other more common causes of reduced athletic performance in childhood.

Among patients with onset of symptoms in adulthood, RYR1 was the most commonly implicated gene. The proportion was higher than observed in previous large CM cohorts mainly comprising pediatric patients. ${ }^{7,29}$

We found that variants in $\mathrm{CM}$ genes were associated with a spectrum of adult-onset phenotypes, including patients with only episodic symptoms or asymptomatic hyperCKemia. Although most patients (80\%) had fixed weakness, the degree and pattern of weakness were variable. In addition to limb weakness, facial weakness was common, but ptosis and ophthalmoparesis, 2 classic features of $\mathrm{CM}$, were only present in a single patient. Although CMs are often thought to represent static or only slowly progressive conditions, ${ }^{6}$ we found that most adult patients with $\mathrm{CM}$ reported a progressive rather than static course. Contrary to pediatric-onset patients, $\mathrm{CK}$ elevations were common among adult-onset CM patients, likely due to the higher proportion of RYR1 myopathy among these patients.

Among adult-onset patients, the most frequent misdiagnoses were non-neurologic conditions, such as rheumatologic and orthopedic disorders. We suspect that the insidious onset of weakness and the lack of awareness of CM among adult neurologists and other physicians precluded appropriate investigations and contributed to diagnostic delays and misdiagnoses. In addition, the misinterpretation of electrodiagnostic findings, which in chronic myopathies, can sometimes resemble a primary neurogenic process, ${ }^{30}$ also played a role in the misdiagnosis. Indeed, we found that longduration MUPs were common among our cohort and, in most cases, could not be accounted for by a neurogenic process.

A cardiomyopathy was present in $29 \%$ of patients who underwent an echocardiogram. This proportion is higher than previously reported ${ }^{29}$ and may reflect a progression of cardiac disease over patients' lifespans. Two patients, however, had evidence of acquired cardiac disorders (ischemic heart disease and tricuspid regurgitation), and a contribution from acquired cardiac disorders cannot be excluded in the remainder. Respiratory muscle weakness and sleep disordered breathing were also common among our patients with $\mathrm{CM}$, affecting $73 \%$ of those tested. Two patients, both with SELENON myopathy, presented with symptoms of respiratory muscle weakness, which preceded the onset of limb weakness and led to misdiagnoses of pulmonary disorders. We also found that respiratory involvement was more common and more severe among pediatric-onset than adult-onset patients.

Among patients with distinctive histologic findings, we found that genetic testing had a yield of $85 \%$. This is in line with previous predominantly pediatric studies, which had found that a molecular diagnosis could be established in $57 \%-79 \%$ of patients with $\mathrm{CM}^{7,29,31}$ Conversely, among patients with a molecular diagnosis, we found that only $42 \%$ had any of the distinctive histopathologic features of a CM. Core myopathies (central core and multiminicore disease) were the most common histologic subtypes. The frequency of nonspecific muscle biopsies in our cohort is significantly higher than previously reported and indicates that muscle biopsy has a lower sensitivity for CM in adults. This difference is unlikely to be explained by the genetic makeup of our cohort, as it was similar to previously reported cohorts. Indeed, nonspecific histologic findings were observed with variants in 5 of the 8 different causative genes identified ( $M Y H 2$, MYH7, ACTA1, SELENON, and RYR1). The absence of distinctive histopathologic features has also previously been observed in young patients with $\mathrm{CM}$, leading to the suggestion that these features only emerge over time as a result of muscle maturation and length of disease activity. The finding of a high proportion of nonspecific muscle biopsies in adult patients with $\mathrm{CM}$, however, indicates that this is not always the case. Similarly, it has been suggested that CFTD may represent an early change anticipating the development of more specific structural abnormalities, rather than a distinct histopathologic entity. Our finding of persistent CFTD in adult patients with $\mathrm{CM}$, however, supports the latter possibility.

Our data indicate that clinical phenotypes deviating from the classical descriptions of $\mathrm{CM}$ are common, as are nonspecific biopsy findings. This suggests that NGS targeting CM genes could be the initial diagnostic tool in patients with suspected $\mathrm{CM}$ and should also be included in the investigation of adult patients with inherited myopathies.

In some inherited myopathies, correlations have been established between genotype and age at onset. ${ }^{22,32,33}$ Among our cohort, such correlations were difficult to identify because of the limited number of patients with variants in each specific gene. We note, however, that in 3/7 families, there were family members exhibiting both pediatric and adult onset. This suggests that additional factors may influence the age at onset.

Although not included in our analysis, we also identified 3 patients with congenital muscular dystrophies caused by variants in collagen genes (COL6A1, COL6A3, and 
COL12A1) that were diagnosed in adulthood during the same period. All 3 had onset of symptoms in adolescence or adulthood and faced diagnostic delays and misdiagnoses similar to those experienced by patients with CM.

This study has some limitations. We performed a retrospective review of data collected in the course of patients' clinical care, and therefore, not all parameters were available for every patient. The course of illness was also assessed retrospectively on the basis of patients' reports, as longitudinal follow-up to objectively assess disease progression was unavailable for most patients. Finally, additional cases of CM may have gone undetected among those patients with nonspecific histologic findings who did not undergo genetic testing.

Nevertheless, our study expands the spectrum of CM by further characterizing the subgroup of patients presenting in adulthood or diagnosed in adulthood. Compared with previous cohorts of mainly pediatric patients, adult-onset patients with CM typically report progressive weakness and often lack the characteristic histologic abnormalities associated with $\mathrm{CM}$. This high prevalence of nonspecific histologic findings signals the need for a revision of the current histologically based classification of CM. Last, we found that adult patients with CM commonly experience delays in diagnosis and misdiagnoses, emphasizing the need for greater awareness of these disorders among adult neurologists. Indeed, the occurrence of "congenital" myopathies in adulthood may warrant the introduction of a different name for this group of disorders.

\section{Study funding}

This study was funded by a donation from Mr. John N. Lawyer.

\section{Disclosure}

Disclosures available: Neurology.org/NG.

\section{Publication history}

Received by Neurology: Genetics February 8, 2019. Accepted in final form April 29, 2019.

\section{Appendix Authors}

\begin{tabular}{|c|c|c|c|}
\hline Name & Location & Role & Contribution \\
\hline $\begin{array}{l}\text { Stefan } \\
\text { Nicolau, MD }\end{array}$ & $\begin{array}{l}\text { Mayo } \\
\text { Clinic }\end{array}$ & Author & $\begin{array}{l}\text { Acquisition, analysis, and } \\
\text { interpretation of data and writing } \\
\text { of the first draft of the manuscript }\end{array}$ \\
\hline $\begin{array}{l}\text { Teerin } \\
\text { Liewluck, } \\
\text { MD }\end{array}$ & $\begin{array}{l}\text { Mayo } \\
\text { Clinic }\end{array}$ & Author & $\begin{array}{l}\text { Critical revision of the manuscript } \\
\text { for intellectual content }\end{array}$ \\
\hline $\begin{array}{l}\text { Jennifer } \\
\text { Tracy, MD }\end{array}$ & $\begin{array}{l}\text { Mayo } \\
\text { Clinic }\end{array}$ & Author & $\begin{array}{l}\text { Critical revision of the manuscript } \\
\text { for intellectual content }\end{array}$ \\
\hline $\begin{array}{l}\text { Ruple } \\
\text { Laughlin, } \\
\text { MD }\end{array}$ & $\begin{array}{l}\text { Mayo } \\
\text { Clinic }\end{array}$ & Author & $\begin{array}{l}\text { Critical revision of the manuscript } \\
\text { for intellectual content }\end{array}$ \\
\hline $\begin{array}{l}\text { Margherita } \\
\text { Milone, MD, } \\
\text { PhD }\end{array}$ & $\begin{array}{l}\text { Mayo } \\
\text { Clinic }\end{array}$ & Author & $\begin{array}{l}\text { Study concept and design, } \\
\text { analysis and interpretation of } \\
\text { data, and study supervision }\end{array}$ \\
\hline
\end{tabular}

\section{References}

1. Romero NB, Clarke NF. Congenital myopathies. Handb Clin Neurol 2013;113: 1321-1336.

2. Jungbluth $\mathrm{H}$, Treves $\mathrm{S}$, Zorzato $\mathrm{F}$, et al. Congenital myopathies: disorders of excitation-contraction coupling and muscle contraction. Nat Rev Neurol 2018;14: 151-167.

3. North $\mathrm{KN}$, Wang $\mathrm{CH}$, Clarke N, et al. Approach to the diagnosis of congenital myopathies. Neuromuscul Disord 2014;24:97-116.

4. Mah JK, Joseph JT. An overview of congenital myopathies. Continuum (Minneap Minn) 2016;22:1932-1953.

5. Malfatti E, Romero NB. Nemaline myopathies: state of the art. Rev Neurol (Paris) 2016;172:614-619.

6. Wang $\mathrm{CH}$, Dowling JJ, North $\mathrm{K}$, et al. Consensus statement on standard of care for congenital myopathies. J Child Neurol 2012;27:363-382.

7. Witting N, Werlauff U, Duno M, Vissing J. Phenotypes, genotypes, and prevalence of congenital myopathies older than 5 years in Denmark. Neurol Genet 2017;3:e140.

8. Norwood FL, Harling C, Chinnery PF, Eagle M, Bushby K, Straub V. Prevalence of genetic muscle disease in Northern England: in-depth analysis of a muscle clinic population. Brain 2009; 132:3175-3186.

9. Cassandrini D, Trovato R, Rubegni A, et al. Congenital myopathies: clinical phenotypes and new diagnostic tools. Ital J Pediatr 2017;43:101.

10. Gonorazky HD, Bönnemann CG, Dowling JJ. The genetics of congenital myopathies. Handb Clin Neurol 2018;148:549-564.

11. Liewluck T, Sorenson EJ, Walkiewicz MA, Rumilla KM, Milone M. Autosomal dominant distal myopathy due to a novel ACTA1 mutation. Neuromuscul Disord 2017;27:742-746

12. Snoeck M, van Engelen BG, Küsters B, et al. RYR1-related myopathies: a wide spectrum of phenotypes throughout life. Eur J Neurol 2015;22:1094-1112.

13. Voermans NC, Snoeck M, Jungbluth H. RYR1-related rhabdomyolysis: a common but probably underdiagnosed manifestation of skeletal muscle ryanodine receptor dysfunction. Rev Neurol (Paris) 2016;172:546-558.

14. Echaniz-Laguna A, Biancalana V, Bohm J, Tranchant C, Mandel JL, Laporte J. Adult centronuclear myopathies: a hospital-based study. Rev Neurol (Paris) 2013;169:625-631

15. Zukosky K, Meilleur K, Traynor BJ, et al. Association of a novel ACTA1 mutation with a dominant progressive scapuloperoneal myopathy in an extended family. JAMA Neurol 2015;72:689-698.

16. Lehtokari VL, Gardberg M, Pelin K, Wallgren-Pettersson C. Clinically variable nemaline myopathy in a three-generation family caused by mutation of the skeletal muscle alpha-actin gene. Neuromuscul Disord 2018;28:323-326.

17. Böhm J, Biancalana V, Malfatti E, et al. Adult-onset autosomal dominant centronuclear myopathy due to BIN1 mutations. Brain 2014;137:3160-3170.

18. Fiorillo C, Astrea G, Savarese M, et al. MYH7-related myopathies: clinical, histopathological and imaging findings in a cohort of Italian patients. Orphanet J Rare Dis 2016;11:91.

19. Garibaldi M, Fattori F, Bortolotti CA, et al. Core-rod myopathy due to a novel mutation in BTB/POZ domain of KBTBD13 manifesting as late onset LGMD. Acta Neuropathol Commun 2018;6:94.

20. Schnitzler LJ, Schreckenbach T, Nadaj-Pakleza A, et al. Sporadic late-onset nemaline myopathy: clinico-pathological characteristics and review of 76 cases. Orphanet J Rare Dis $2017 ; 12: 86$.

21. Oliveira J, Gruber A, Cardoso M, et al. LAMA2 gene mutation update: toward a more comprehensive picture of the laminin-alpha2 variome and its related phenotypes. Hum Mutat 2018;39:1314-1337.

22. Bönnemann CG. The collagen VI-related myopathies Ullrich congenital muscular dystrophy and Bethlem myopathy. Handb Clin Neurol 2011;101:81-96.

23. Bouchet-Seraphin C, Vuillaumier-Barrot S, Seta N. Dystroglycanopathies: about numerous genes involved in glycosylation of one single glycoprotein. J Neuromuscul Dis 2015;2:27-38.

24. Niu Z, Pontifex CS, Berini S, et al. Myopathy with SQSTM1 and TIA1 variants: clinical and pathological features. Front Neurol 2018;9:147.

25. Laughlin RS, Niu Z, Wieben E, Milone M. RYR1 causing distal myopathy. Mol Genet Genomic Med 2017;5:800-804.

26. Rossi D, De Smet P, Lyfenko A, et al. A truncation in the RYR1 gene associated with central core lesions in skeletal muscle fibres. J Med Genet 2007;44:e67.

27. Brand P, Dyck PJ, Liu J, Berini S, Selcen D, Milone M. Distal myopathy with coexisting heterozygous TIA1 and MYH7 Variants. Neuromuscul Disord 2016;26:511-515.

28. Richards S, Aziz N, Bale S, et al. Standards and guidelines for the interpretation of sequence variants: a joint consensus recommendation of the American College of Medical Genetics and Genomics and the Association for Molecular Pathology. Genet Med 2015; 17:405-424.

29. Colombo I, Scoto M, Manzur AY, et al. Congenital myopathies: natural history of a large pediatric cohort. Neurology 2015;84:28-35.

30. Uncini A, Lange DJ, Lovelace RE, Solomon M, Hays AP. Long-duration polyphasic motor unit potentials in myopathies: a quantitative study with pathological correlation. Muscle Nerve 1990;13:263-267.

31. Maggi L, Scoto M, Cirak S, et al. Congenital myopathies: clinical features and frequency of individual subtypes diagnosed over a 5-year period in the United Kingdom. Neuromuscul Disord 2013;23:195-205.

32. Pogoryelova O, Wilson IJ, Mansbach H, Argov Z, Nishino I, Lochmuller H. GNE genotype explains $20 \%$ of phenotypic variability in GNE myopathy. Neurol Genet 2019;5:e308.

33. Sveen ML, Schwartz M, Vissing J. High prevalence and phenotype-genotype correlations of limb girdle muscular dystrophy type 2I in Denmark. Ann Neurol 2006;59: 808-815. 


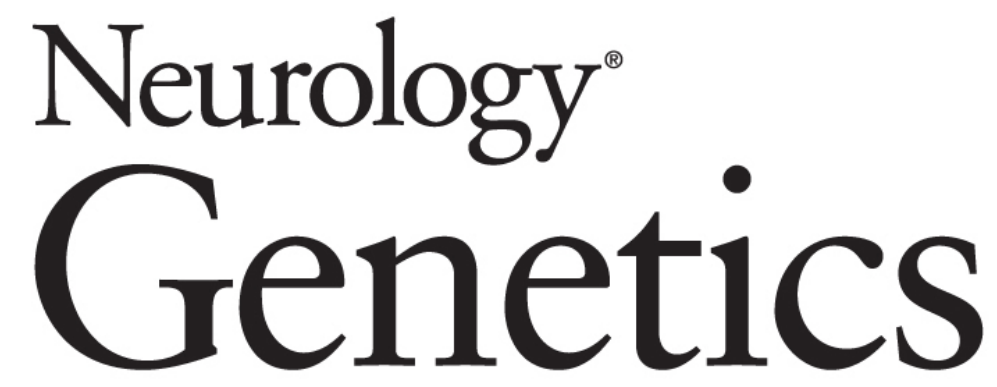

Congenital myopathies in the adult neuromuscular clinic: Diagnostic challenges and pitfalls

Stefan Nicolau, Teerin Liewluck, Jennifer A. Tracy, et al.

Neurol Genet 2019;5;

DOI 10.1212/NXG.0000000000000341

This information is current as of June 4, 2019

Neurol Genet is an official journal of the American Academy of Neurology. Published since April 2015, it is an open-access, online-only, continuous publication journal. Copyright Copyright $\odot 2019$ The Author(s).

Published by Wolters Kluwer Health, Inc. on behalf of the American Academy of Neurology.. All rights reserved. Online ISSN: 2376-7839.

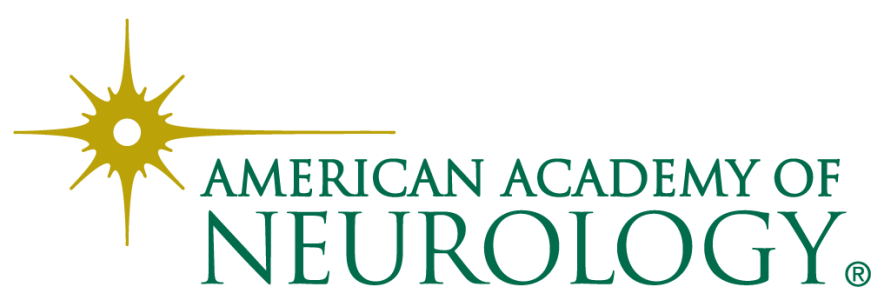




\section{Updated Information \& Services}

References

Citations

Subspecialty Collections

Permissions \& Licensing

Reprints including high resolution figures, can be found at: http://ng.neurology.org/content/5/4/e341.full.html

This article cites 33 articles, 3 of which you can access for free at: http://ng.neurology.org/content/5/4/e341.full.html\#\#ref-list-1

This article has been cited by 3 HighWire-hosted articles: http://ng.neurology.org/content/5/4/e341.full.html\#\#otherarticles

This article, along with others on similar topics, appears in the following collection(s):

All Clinical Neurology

http://ng.neurology.org//cgi/collection/all_clinical_neurology All Genetics http://ng.neurology.org//cgi/collection/all_genetics

\section{All Neuromuscular Disease}

http://ng.neurology.org//cgi/collection/all_neuromuscular_disease Muscle disease

http://ng.neurology.org//cgi/collection/muscle_disease

Information about reproducing this article in parts (figures,tables) or in its entirety can be found online at:

http://ng.neurology.org/misc/about.xhtml\#permissions

Information about ordering reprints can be found online: http://ng.neurology.org/misc/addir.xhtml\#reprintsus

Neurol Genet is an official journal of the American Academy of Neurology. Published since April 2015, it is an open-access, online-only, continuous publication journal. Copyright Copyright $\odot 2019$ The Author(s). Published by Wolters Kluwer Health, Inc. on behalf of the American Academy of Neurology.. All rights reserved. Online ISSN: 2376-7839.

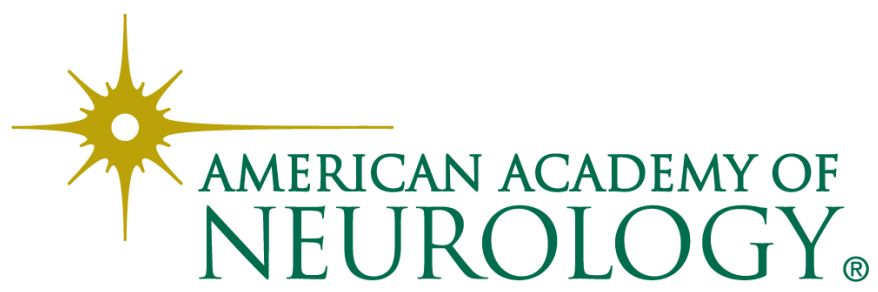

